\title{
ENVIRONMENTALLY-SUSPENDED SEDIMENT PRODUCTION OF THE NASIA RIVER BASIN, NORTHERN GHANA
}

\author{
F. K. Abagale ${ }^{1}$ and N. Kyei-Baffour ${ }^{2}$ \\ Department of Agric Mechanization and Irrigation Technology \\ Faculty of Agriculture \\ University for Development Studies \\ Tamale, Ghana \\ Email: fabagale@yahoo.com
}

\begin{abstract}
Rivers constitute an important source of surface water supply for most sectors in the world. In areas with single rainfall maximum, as in the north of Ghana, the rivers are normally intermittent or ephemeral with only few perennial ones. The Nasia River Basin is the drainage basin of the left bank tributary of the White Volta within the Guinea Savannah Ecological Zone and lies in the Northern Region of Ghana. The study assessed the level of suspended sediment produced in the Nasia River Basin. Hydrological and meteorological data and water samples were used for the study. Average suspended sediment yield (33 years) in the basin was $19.90 \mathrm{t} / \mathrm{km}^{2} / \mathrm{yr}$. With mean annual runoff of $439.13 \mathrm{~m}^{3} / \mathrm{s}, 322.43 \mathrm{t} / \mathrm{yr}$ suspended sediment is discharged into the White Volta from the Nasia River. Mean suspended sediment concentration and turbidity values for three months of continuous study were $423.86 \mathrm{mg} / \mathrm{l}$ and 406.19 NTU respectively. The mean discharged suspended sediment of $0.13 \mathrm{~kg} / \mathrm{s}, 0.25 \mathrm{~kg} / \mathrm{s}$ and $1.31 \mathrm{~kg} / \mathrm{s}$ were recorded for April, May and June 2007 respectively for the basin. These levels of suspended sediment deposited in the river bed reduce the carrying capacity of this water system. The study realised that catchment characteristics have a great influence on suspended sediment production in the Nasia River Basin. The reduction of the level of erosion and suspended sediment transport and deposition in the river bed is therefore very important.
\end{abstract}

KEY DESCRIPTORS: River Basin, Drainage System, Guinea Savannah, Suspended Sediment, Turbidity.

\section{INTRODUCTION}

\section{Background}

Rivers have been noted to constitute an important source of surface water supply for most sectors in the world. In areas with single rainfall maximum, as in the north of Ghana, rivers are normally intermittent or ephemeral with only few perennial rivers. However, in areas with high and well distributed rainfall within the year, the rivers flow throughout the year. Streams of northern Ghana which are tributaries of the Volta system are not permanent and therefore do not contain enough water

\footnotetext{
${ }^{1}$ Lecturer, Department of Agricultural Mechanisation and Irrigation Technology, Faculty of Agriculture, University for Development Studies, Tamale, Ghana.

${ }^{2}$ Associate Professor, Department of Agricultural Engineering, Faculty of Mechanical and Agricultural Engineering, Kwame Nkrumah University of Science and Technology, Kumasi, Ghana.
} 
during the dry seasons. Lower rainfall amounts coupled with longer dry season periods over the years have led to more tributaries as well as streams and rivers drying up quickly. A drainage area which is synonymous to drainage basin or catchment area is the entire area providing runoff to, and sustaining part or all of the stream flow of the main stream channel and its tributaries. River basin on the other hand is a geographical unit that defines an area where various users of the basin water interact, and where most of them live (Bandaragoda, 2001). For generations, rivers have been the backbone for many human settlements throughout the world as they have a role of providing water needs.

According to EPA (2002), degraded lands in the deforestation-prone zone of northern Ghana cause downstream flooding, reduced water quality, sedimentation in rivers and lakes and siltation of reservoirs (dams and dugouts). Morgan (1995) indicated that part of the sediment removed from hillsides, embankments and cuttings finds its way into rivers but part is deposited at the bottom of slopes and in flood plains where it remains in temporary storage, sometimes until the next storm, or, at other times, as in the case of colluvial material for millions of years.

In the West African Savannah of northern Ghana, soil loss rates have been measured at between 0.9 and $6.2 \mathrm{t} / \mathrm{ha} / \mathrm{yr}$ with slopes of only $1 \%$ and $2 \%$ (Asiamah and Antwi, 1988). The soil particles eroded from these areas end up in streams and rivers thus reducing their carrying capacity and also causing flooding of the banks of these water carrying systems.

Soils are particularly prone to erosion in both East and West African Savannah as they are predominantly sands, sandy loams and black cracking clays that have a weak structural stability. Moreover the organic matter content is often low (Quansah, 1990). More importantly, alternating distinct dry and wet periods accelerate high erosion rates at the onset of the rainy season when the ground cover is poor or lacking. In the West African Savannah in Northern Ghana, soil loss rates have been measured at between 0.9 and 6.2 t.ha $^{-1} \mathrm{yr}^{-1}$ with slopes of only one and two percent (Asiamah \& Antwi, 1988).

There is rapidly increasing demand for water for industrial use especially in agriculture production, hydropower generation, mining activities and, recreation, domestic and environmental enhancement. If these demands for water continue to increase then water supplies will be over stretched and pollution problems as well as environmental degradation will also increase tremendously. These problems would be more pronounced if population and urbanisation continues to increase as well as the diversification of human activities.

Irrigation of crops in the country is traditionally on low scale due to the country's dependence on rainfed agriculture (EPA, 2000), therefore the sustenance of maximum river and stream flows would allow for the proper harnessing of the surface water resources. In Northern Ghana farmers are being encouraged to adopt the use of rivers and streams for dry season farming. This involves the clearing and use of river banks and other land areas close to these water systems and this normally employ the use of water lifting machines for crop irrigation.

The study examined the suspended sediment production and concentration levels of the Nasia River and also established the relationship between suspended sediment production, river flow pattern and water turbidity.

\section{River Systems in the West Africa Savannahs}

According to George (2005), even though there is considerable runoff in tropical West and Central Africa, the overall runoff of the continent is lower than the runoff in North and Central America which 
have a land area of only $80 \%$ of that of Africa. The effectiveness of rainfall in the area is reduced as a result of high rates of evaporation at $570 \mathrm{~mm} /$ year and its effects on the seasonality of the river flow regimes. George also indicated that Africa would require only $0.5-1 \%$ of the stable runoff or a maximum of $1.06 \times 10^{10} \mathrm{~m}^{3} /$ year to adequately supply the needs of its entire population although the Congo basin has been reported to contribute over $50 \%$ of the total river runoff.

Rivers constitute an important source of surface water supply in Ghana and there are three main river systems that drain the country. These are the Volta River System, the South-Western River system and the Coastal River System. These cover $70 \%, 22 \%$ and $8 \%$ respectively of the total area of Ghana. The Volta River system consists of the Black, White and Main/Lower Volta and Oti and Daka Rivers. The South-Western system comprises the Bia, Tano, Ankobra and Pra rivers. The Coastal system consists of the Chi-Nakwa, Ochi-Amissah, Ayensu, Densu and the Tordzie rivers (MWH, 1998). The two main sources of water supply for the rivers are rainfall and spring.

The Volta River Basin spans a large stretch of the West African sub-region. It lies within latitudes $5^{0} 30^{1} \mathrm{~N}$ and $14^{0} 30^{1} \mathrm{~N}$ and longitudes $2^{0} 00^{1} \mathrm{E}$ and $5^{0} 30^{1} \mathrm{~W}$. The main channel is $1,400 \mathrm{~km}$. It drains $400,000 \mathrm{~km}^{2}$ of the semi - arid and sub-humid savannah area. The basin lies mainly in Ghana (42\%), Burkina Faso (43\%), and the remaining $15 \%$ in Mali, Cote d'Ivoire, Togo and Benin (Nick Van et al, 2001).

The Volta River is by far the longest river in Ghana. Within its basin lies nearly three - quarters of the total land surface area of the country. The huge basin can be divided into smaller basins belonging to the Black Volta, the White Volta, the Oti, and the Volta which here refers to the continuation of the Black Volta downstream from the confluence with the White Volta. It is these rivers which together with their numerous tributaries form the Volta River system. The annual mean, monthly maximum and monthly minimum flows of the White Volta which has a drainage area of $45,800 \mathrm{~km}^{2}$ are $10.28 \mathrm{~m}^{3} /$ day, $104.98 \mathrm{~m}^{3} /$ day and $0.09 \mathrm{~m}^{3} /$ day respectively (Opoku - Ankoma, 1986). The total annual discharge leaving Burkina Faso through the Red and White Volta rivers is estimated at $3.7 \mathrm{~km}^{3} /$ year $(F A O, 1997)$.

Ghana's total renewable water resources are estimated to be $53.2 \mathrm{~km}^{3} /$ year of which $30.3 \mathrm{~km}$ /year is internally produced. About $22.9 \mathrm{~km}^{3}$ of surface water enter the country annually of which $8.7 \mathrm{~km}^{3}$ comes from Burkina Faso, $6.2 \mathrm{~km}^{3}$ from Cote d'Ivoire and $8 \mathrm{~km}^{3}$ from Togo (FAO, 2005). The runoff yield in the various river basins generally follows the rainfall pattern. During the months of June, July and October when rainfall is heaviest in the south of the country, flows are high. In Northern Ghana, where rainfall is uni-modal, high flows occur in August through October. The dry season extends from November to March and low flows are observed during this period throughout the country (EPA, 2002).

Many other tributaries of the White Volta such as the Nasia River have their sources within Ghana, especially in the Northern Savannah part. Most of these water courses run almost dry after the rains thus affecting many sectors of the country.

\section{Suspended Sediment and River Flow}

The world's average yield of sediment and solutes by rivers is equivalent to a lowering of the earth's surface by $3 \mathrm{~cm}$ every 1000 years or $42 \mathrm{t} \cdot \mathrm{km}^{-2} \cdot \mathrm{yr}^{-1}$ (Lal, 1990). According to Gregory and Walling (1973) the denudation rates or the annual suspended sediment discharge rates are 27, 35, 45, 63, 96, and 600 $\mathrm{t} . \mathrm{km}^{-2} \cdot \mathrm{y}^{-1}$ for Africa, Europe, Australia, South America, North America, and Asia respectively.

Sediment transport in channels, streams, and rivers must be assessed to compute the erosion over the watershed. The rate of erosion is computed by using the techniques of measurement of water runoff and sediment transport in streams, rivers, and large watershed areas. Monitoring sediment transport 
rates at a point in the river channel is the basic method and information obtained from this indicates the trends of erosion even though it may be difficult to relate the sediment source to soil properties, landforms, or land use. The concentrations of sediment vary at different locations in the stream cross section (Lal, 1990).

\section{MATERIALS AND METHODS}

\section{Study Area}

The Nasia River Basin lies between latitude $9^{\circ} 55^{\prime \prime}$ and $10^{\circ} 40^{\prime \prime} \mathrm{N}$ and longitude $1^{\circ} 05^{\prime \prime} \mathrm{W}$ and $0^{\circ} 15^{\prime \prime} \mathrm{E}$ (Adu, 1995). The basin lies within the Northern Region of Ghana and it is the drainage basin of the left bank tributary of the White Volta. Geologically, Adu (1995) states that the basin lies on Voltaian sediments. The soils of the area are developed over Upper Voltaian sandstones, Lower Voltaian shales and alluvial floodplains and slough. Figure 1 below shows the Nasia River Basin (Study Area) and the sampling points (shaded area with bullets).

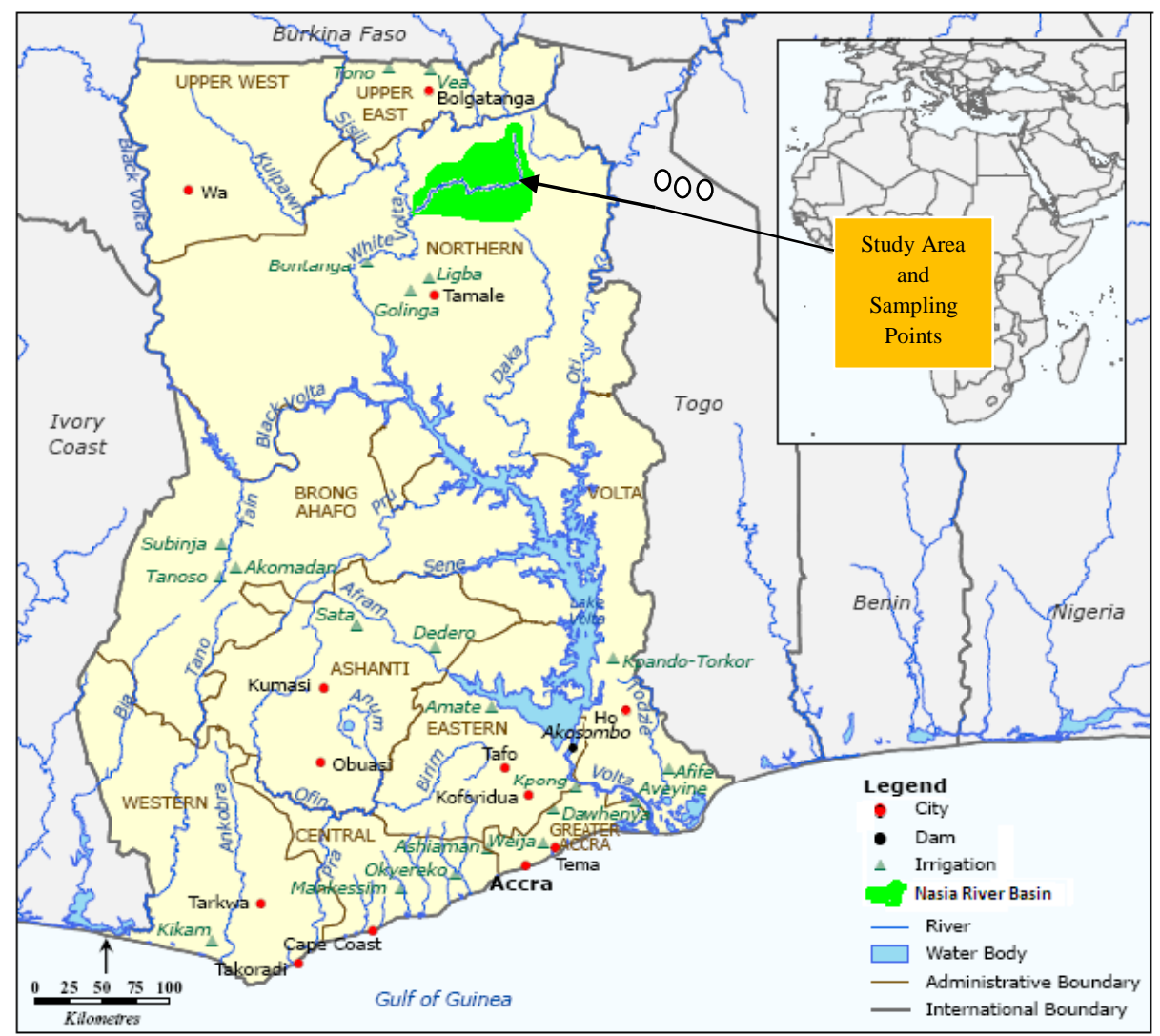

Figure 1: Map of Ghana showing the Nasia River Basin and Sampling Points

\section{Materials and Data collection}

Data used for the study include rainfall, river discharge, topographic maps, slope data and information on the Nasia soils. Instrumentation for the study include a HAFF-Planimeter No. 317, 2020

Turbidimeter, water sample bottles, desiccator, drying oven and weighing scale. Three samples of a 
litre each of daily surface dip samples of water were collected from three different locations at the gauge point of the river channel during the months of April, May and June 2007 at which time the vegetation cover of the basin could be said to be non-existent or less luxuriant.

Thirty three (33) years (1974 - 2006) of daily gauged river flows of the Nasia River were obtained from Architectural and Engineering Services Limited (Hydro Division) in Tamale, Ghana as well as daily river flow data for April, May and June 2007.

\section{Methods}

\section{Regression Models of Sediment Yield Estimation}

Empirical models relating sediment yield to the characteristics of rainfall, runoff, and watershed have been used in establishing the sediment yields for the various years of study of the Nasia River Basin. According to Gregory and Walling (1973), a model developed by Fournier (1960) which devised a relief factor and used with the precipitation index $\left(\frac{p^{2}}{P}\right)$ to produce a single empirical equation for the prediction of sediment yields was used and is given by:

$$
\log Q_{s}=2.65 \log \frac{p^{2}}{P}+0.46 \log \frac{H^{2}}{S}-1.56
$$

Where;

$\mathrm{Q}_{\mathrm{s}}$ - Mean annual suspended sediment yield $\left(\mathrm{t} / \mathrm{km}^{2} / \mathrm{yr}\right), \mathrm{H}$ - Mean relief of the basin or the difference between the mean altitude and the minimum altitude $(\mathrm{m}), \mathrm{S}-$ Catchment area $\left(\mathrm{km}^{2}\right), \mathrm{p}-$ Rainfall $(\mathrm{mm})$ in the wettest month and $\mathrm{P}-$ Mean annual rainfall $(\mathrm{mm})$.

The rating relationship for suspended sediment and the river discharge was used to establish the rating predictive model for the basin and this is given as:

$$
Q_{s}=a Q_{w}{ }^{b}
$$

Where; $Q_{s}=$ sediment discharge $\left(\mathrm{t} / \mathrm{km}^{2} / \mathrm{yr}\right), \mathrm{Q}_{\mathrm{w}}=$ water discharge $\left(\mathrm{m}^{3} / \mathrm{s}\right), \mathrm{b}=$ exponent and $a=$ constant.

\section{Suspended Sediment Concentration Analysis}

The evaporation method of sediment concentration analysis of water samples as indicated by Millar (1994) was used in the laboratory for suspended sediment concentration determination. Suspended sediment concentration was calculated using equation 3 .

$$
\begin{aligned}
& \text { Sediment Concentration }\left(\frac{m g}{l}\right) \\
& \quad=(\text { Weight of Container }+ \text { Weight of Sediment }) \\
& - \text { Weight of Container ............... (3) }
\end{aligned}
$$


A procedure developed for use with depth-integrating samplers by Guy and Norman (1970) was used for calculating the suspended sediment discharge. The sediment discharge which is calculated as the product of discharge and concentration is given as:

$$
Q_{s}=\frac{Q C_{s}}{1000}
$$

Where; $\mathrm{Q}_{\mathrm{s}}=$ sediment discharge $(\mathrm{kg} / \mathrm{s}), \mathrm{Q}=$ stream discharge $\left(\mathrm{m}^{3} / \mathrm{s}\right)$, and $\mathrm{C}_{\mathrm{s}}=$ suspended sediment concentration $(\mathrm{mg} / \mathrm{l})$.

\section{Turbidity Level Determination}

Turbidity levels of the water samples were determined using a 2020 turbidimeter in the laboratory and turbidity levels were represented in Nephelometric Turbidity Units (NTU). The instrument had 0.05 or \pm $2 \%$ accuracy level for readings below 100 NTU and $\pm 3 \%$ for readings above 100 NTU whilst the readings ranged from $0.00-1100$ NTU.

\section{RESULTS AND DISCUSSIONS}

\section{Suspended Sediment Yield of the Nasia River Basin}

Environmental sediment production as a result of erosion of catchment areas of river and stream basins has been realised to have a great impact on the ecosystem as well as the discharge capacity of these water systems. Prediction of suspended sediment produced from the Nasia River Basin were categorised into five (5) drainage areas and the results are presented in Table 1. The average slope of the whole basin area is $7.54^{\circ}(14.2 \%)$ with the mean altitude being $250 \mathrm{~m}$. According to Gregory and Walling (1973) parameters such as geology, topography, meteorological variables, and etc for sediment and solute production reflect the operation of fluvial processes in a drainage basin much more directly than indices of runoff, because they are themselves measures of the intensity of denudation.

The average amount of suspended sediment produced in the river basin for 33 years was $19.90 \mathrm{t} / \mathrm{km}^{2} / \mathrm{yr}$ (Table 1). However, a mean annual suspended sediment yield of $32.56 \mathrm{t} / \mathrm{km}^{2} / \mathrm{yr}$ for the White Volta have been reported by Akrasi (2005) which is almost twice that of the Nasia River Basin thus indicating a high specific mean suspended sediment yield of $19.9 \mathrm{t} / \mathrm{km}^{2} / \mathrm{yr}$.

Table 1: Predicted Suspended Sediment of the Nasia River Basin

\begin{tabular}{|c|c|c|c|c|c|c|}
\hline \multirow[b]{2}{*}{ Drainage Area } & \multirow{2}{*}{$\begin{array}{l}\text { Area } \\
\left(\mathrm{km}^{2}\right)\end{array}$} & \multirow{2}{*}{$\begin{array}{l}\text { Average } \\
\text { Altitude } \\
(\mathrm{m})\end{array}$} & \multirow{2}{*}{$\begin{array}{l}\text { Average } \\
\text { Slope in } \\
\text { Degrees } \\
\text { (') }\end{array}$} & \multicolumn{3}{|c|}{$\begin{array}{l}\text { Suspended Sediment Yield } \\
\text { (t/km²/yr) for } 32 \text { Years } \\
(1974-2006)\end{array}$} \\
\hline & & & & Minimum & Mean & Maximum \\
\hline Scarp Lands & 524.31 & 449.0 & 15.9 & 3.52 & 4.36 & 5.55 \\
\hline Gambaga Highlands & 331.83 & 308.0 & 12.2 & 3.23 & 4.07 & 5.26 \\
\hline Piedmont Slopes & $1,053.67$ & 216.0 & 6.4 & 3.07 & 3.90 & 5.10 \\
\hline Peneplains & $1,186.45$ & 154.0 & 2.7 & 2.80 & 3.64 & 4.84 \\
\hline $\begin{array}{l}\text { White Volta and Nasia River } \\
\text { Flood Plains \& Sloughs }\end{array}$ & $2,242.85$ & 123.0 & 0.5 & 3.10 & 3.93 & 5.13 \\
\hline
\end{tabular}


Ghana Journal of Development Studies, Volume 7, Number $2 \mid 2010$

\begin{tabular}{|l|l|l|l|l|l|l|} 
Total/Average & $5,339.10$ & 250.0 & 7.54 & 15.72 & 19.90 & 25.88 \\
\hline
\end{tabular}

Source: Fieldwork, 2007.

The minimum sediment yield of $15.72 \mathrm{t} / \mathrm{km}^{2} / \mathrm{yr}$ was recorded in 1986 when the rainfall for the wettest month was $178.5 \mathrm{~mm}$ and the annual total rainfall being $1,083 \mathrm{~mm}$. A maximum sediment yield of 25.88 $\mathrm{t} / \mathrm{km}^{2} \mathrm{yr}$ occurred in the basin when the wettest month of the year recorded a rainfall amount of 495.8 $\mathrm{mm}$ in 1989 with the annual total rainfall of 1,428 mm. According to Gregory and Walling (1973) variation in sediment yield with precipitation could be explained by the interaction of precipitation and vegetation on runoff and erosion. Holeman (1968) reported that the annual suspended sediment discharge for Africa was about $27 \mathrm{t} / \mathrm{km}^{2}$, thus the maximum annual suspended sediment predicted of $25.88 \mathrm{t} / \mathrm{km}^{2}$ for the Nasia River Basin fell below this. From Table 1 the minimum specific suspended sediment value of $2.80 \mathrm{t} / \mathrm{km}^{2} / \mathrm{yr}$ was recorded for the Peneplains area whilst maximum value of 5.5 $\mathrm{t} / \mathrm{km}^{2} / \mathrm{yr}$ was recorded for the Scarp lands.

Although the Peneplains has an area of $1,186.45 \mathrm{~km}^{2}$ and the Gambaga highlands occupied $331.83 \mathrm{~km}^{2}$, a higher mean amount of suspended sediment $\left(4.07 \mathrm{t} / \mathrm{km}^{2} / \mathrm{yr}\right)$ was produced from the Gambaga highlands as compared to $3.64 \mathrm{t} / \mathrm{km}^{2} / \mathrm{yr}$ for the Peneplains thus indicating the effect of slope on suspended sediment production.

Although the catchment area has an influence on the amount of suspended sediment produced, the average slope of an area has a greater influence as can be seen in the results presented in Table 1.

\section{River Discharge and Predicted Suspended Sediment Relations}

As in Figure 2 below, the coefficient of determination $\left(r^{2}\right)$ is closer to $1(0.995)$ indicating a good fit, and meaning that about $99.5 \%$ of the variation in the predicted suspended sediment values are explained by the regression equation.
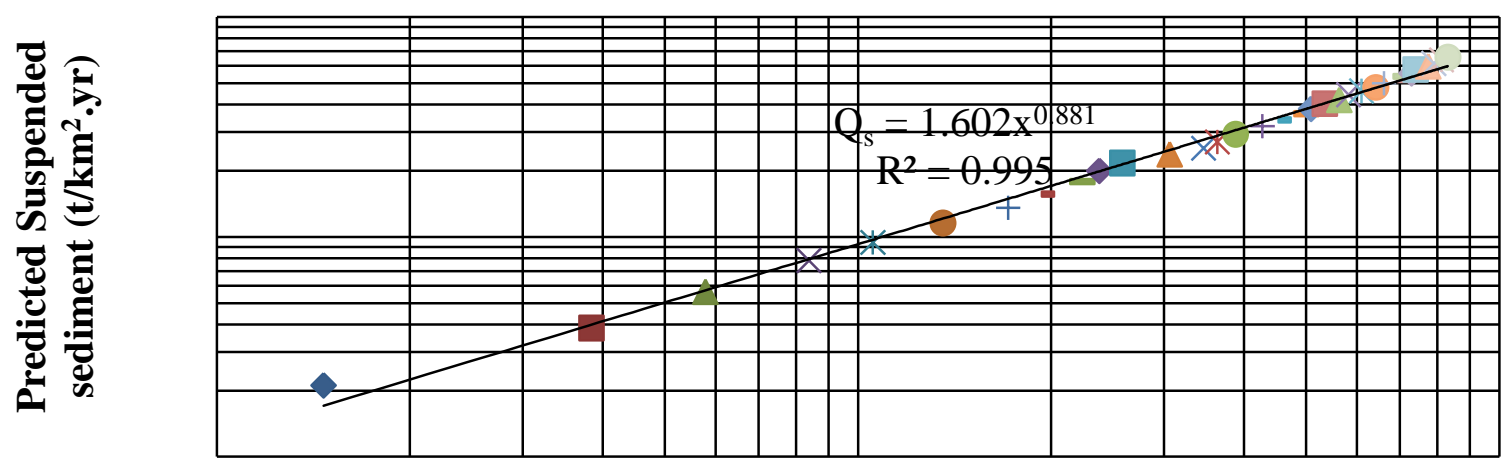

\section{Figure 2: Predicted Suspended Sediment Rating Curve for Nasia Discharge $\left(\mathrm{m}^{3} / \mathrm{s}\right)$ River Basin}

A strong relationship between the predicted suspended sediment and the river discharge is also shown by the correlation coefficient $\left(r^{2}\right)$ of 0.995 . The plot indicates a direct relationship between river discharge and predicted suspended sediment. An increase in suspended sediment produced according to the rating equation resulted in an increase in the discharge rate of this sediment as the river 
discharge increased. This could be attributed to the scouring of the embankment of the river as it overflows its banks and also from high surface runoff of the basin.

Table 2 below provides the relationships fitted for the predicted suspended sediment produced for the five classified drainage areas and the river discharge. All relationships were statistically significant at the $5 \%$ level, with the coefficients of determination $\left(r^{2}\right)$ associated with the five individual relationships being either 0.994 or 0.995 .

Table 2: Parameters for Suspended Sediment Rating Curves for Five Classified Drainage Areas of the Nasia River Basin

\begin{tabular}{|l|l|l|l|}
\hline \multirow{2}{*}{ Classified Drainage Area } & \multicolumn{3}{l}{} \\
\cline { 2 - 4 } & \multicolumn{2}{l}{ Parameter } \\
\hline Scarp Lands & $\mathrm{A}$ & $\mathrm{b}$ & $\mathrm{r}^{2}$ \\
\hline Gambaga Highlands & 0.316 & 0.881 & 0.995 \\
\hline Piedmont Slopes & 0.327 & 0.880 & 0.995 \\
\hline Peneplains & 0.313 & 0.881 & 0.995 \\
\hline White Volta and Nasia River Flood Plains \& Sloughs & 0.292 & 0.881 & 0.994 \\
\hline
\end{tabular}

Source: Fieldwork, 2007

A distinctive feature of the basin plot (Figure 2 ) and the individual area plot are the relatively very low magnitude of the rating exponents and thus the low slope of the rating plots. This indicates the insensitivity of the predicted suspended sediment to an increase in the river discharge. With the exponent of the various areas of the basin and the general basin area being $<1.0$ indicating that suspended sediments produced tended to decrease when the discharge increased. These exponent values as shown in Table 2 above show substantially lower values than the typical values of between 2.0 and 3.0, as cited by Gregory and Walling (1973). These exponent values thus suggest that the river remains turbid over a wide range of flows, and the suspended sediment produced remain relatively high during low flows.

A simple prediction model in the form of Equation 5 was developed on the basis of simple regression analysis of the sediment yield data for the 33 years of the river basin and this is in the form:

$$
\begin{aligned}
& Q_{s}=1.602 Q_{w}{ }^{0.881} \ldots \ldots \ldots \ldots \ldots \ldots \ldots \ldots \ldots \\
& \text { thus, } \quad \log Q_{s}=0.881 \log Q_{w}+0.2047
\end{aligned}
$$

The positive exponent associated with the mean annual run-off indicates that specific suspended sediment yields increase with higher mean annual river discharge thus reflecting the increased erosion and suspended sediment transport associated with the increased discharge. Since increased river flows are experienced after the infiltration rate of the soils are exceeded this model proves that overland flow occurs and results in the routing of more sediment and its consequent deposition in the area.

The results of the study revealed that the average suspended sediment discharged into the White Volta from the Nasia River for the 33 years studied (using Equation 6) with mean annual runoff of $439.13 \mathrm{~m}^{3} / \mathrm{s}$ is $322.43 \mathrm{t} / \mathrm{yr}$. Ferguson (1986) however indicates that the degree of underestimation using this equation increases with the degree of scatter about the rating curve and can reach $50 \%$. With Nasia, Morgo, Bopare, Jolo, Tono, Diegouro, Red Volta, Morago, Yaragatanga, Atamore, Pasam, Atankuidi, 
Sillum, Tamne, Kulpawn, Sissili, Nabogo and Mole (HSD, 2007) being tributaries of the White Volta and the White Volta experiencing a mean annual suspended sediment load of $4 \times 10^{6} \mathrm{t} / \mathrm{yr}$ (Akrasi, 2005), a $322.43 \mathrm{t} / \mathrm{yr}$ predicted for the Nasia tributary is rather low. This low value can however be associated with the relative drainage areas of the various tributaries contributing sediment to the White Volta.

\section{Suspended Sediment Concentration and Turbidity}

Mean suspended sediment concentration (SSC) and turbidity (NTU) values were $274.63 \mathrm{mg} / \mathrm{l}$ and 141.74 NTU for April 2007, $379.45 \mathrm{mg} / \mathrm{l}$ and 423.91 NTU for the month of May 2007 whilst June 2007 recorded $619.00 \mathrm{mg} / \mathrm{l}$ and $652.33 \mathrm{NTU}$ for suspended sediment concentration and turbidity respectively. The greater difference in the suspended sediment concentration and turbidity values for the three months resulted from the differences in rainfall amount and the effect of overland flow. High rainfall values which were recorded for the month of May and June had a significant effect on the detachment and entrainment of soil particles down slope as compared to the low values recorded for April. See Fig 3 below.

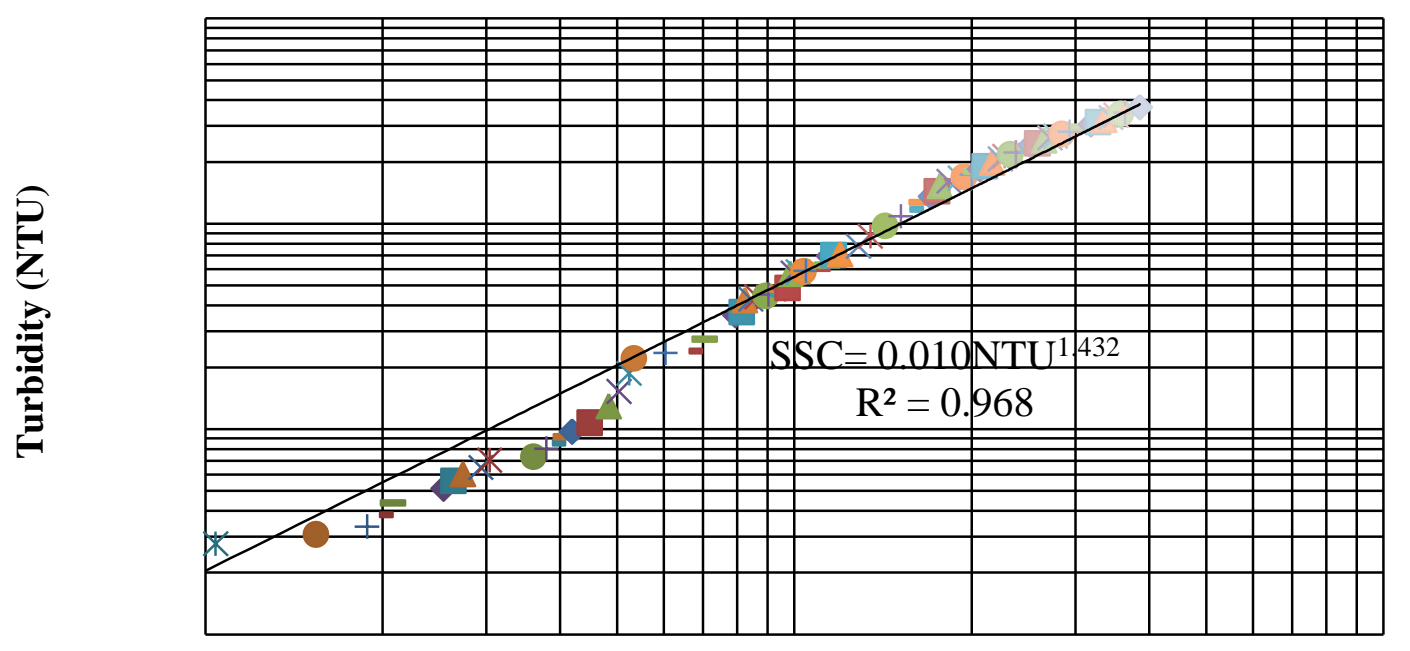

\section{Suspended Sediment Concentration (mg/l)}

\section{Figure 3: Relationship between Turbidity and Suspended Sediment Concentration of the Nasia River}

Generally, high turbidity values resulted in high levels of suspended sediment concentration in the river channel. A good relationship between turbidity and suspended sediment concentration is as shown in Figure 3 above. According to Truhlar (1978), there is no universal relationship between turbidity and suspended sediment concentration, but there is often a good correlation for individual streams, probably because the material in suspension in a stream is a characteristic of the basin.

The model shows a strong positive log-log relationship between turbidity and suspended sediment concentration with correlation coefficient $\left(r^{2}\right)$ of 0.968 for the Nasia River. A better correlation between turbidity and suspended sediment concentration than between water discharge and suspended sediment discharge is usually expected. This is because turbidity and suspended sediment concentration respond similarly to many factors that are not directly related to water discharge (Truhlar, 1978). 
The rating relationship and regression (Equation 7) therefore indicates that an increase in turbidity level of the river resulted in a corresponding increase in suspended sediment concentration. Turbidity has been identified as an effective and inexpensive indicator of suspended sediment (Lewis, 1996). Strong relationships between total suspended sediments and turbidity have been repeatedly and consistently identified (Gippel, 1995).

An established regression equation for the relationship between the suspended sediment concentration and turbidity for the Nasia River is as presented in Equation 7.

$$
\operatorname{logSSC}\left(\frac{m g}{l}\right)=1.432 \log N T U-2.0
$$

\section{Suspended Sediment Concentration - Discharge and Turbidity - Discharge Relations}

The mean discharged suspended sediment for April, May and June 2007 of the Nasia River using Equation 4 was $0.13 \mathrm{~kg} / \mathrm{s}, 0.25 \mathrm{~kg} / \mathrm{s}$ and $1.31 \mathrm{~kg} / \mathrm{s}$ respectively. A minimum and maximum suspended sediment discharge values of $0.04 \mathrm{~kg} / \mathrm{s}$ (river discharge $=0.38 \mathrm{~m}^{3} / \mathrm{s}$ ) and $0.47 \mathrm{~kg} / \mathrm{s}$ (river discharge $=0.52$ $\mathrm{m}^{3} / \mathrm{s}$ ) were recorded for the month of April respectively. The month of May recorded $0.04 \mathrm{~kg} / \mathrm{s}$ (river discharge $=0.40 \mathrm{~m}^{3} / \mathrm{s}$ ) and $0.65 \mathrm{~kg} / \mathrm{s}$ (river discharge $=0.72 \mathrm{~m}^{3} / \mathrm{s}$ ) as minimum and maximum suspended sediment discharged respectively whilst June 2007 had $0.25 \mathrm{~kg} / \mathrm{s}$ (river discharge $=1.67 \mathrm{~m}^{3} / \mathrm{s}$ ) and 2.52 $\mathrm{kg} / \mathrm{s}$ (river discharge $=3.01 \mathrm{~m}^{3} / \mathrm{s}$ ) as minimum and maximum suspended sediment discharged respectively.

Regressing the suspended sediment concentration against the discharge for the three months results in a simple model of suspended sediment concentration:

$$
\log S S C\left(\frac{m g}{l}\right)=1.024(\log Q s)+2.645
$$

It can be seen from the curve (Figure 4) that, the coefficient of determination $\left(r^{2}\right)$ is closer to $1(0.975)$ indicating a good fit, and meaning that about $97.5 \%$ of the variation in the suspended sediment concentration values are explained by the regression equation. 

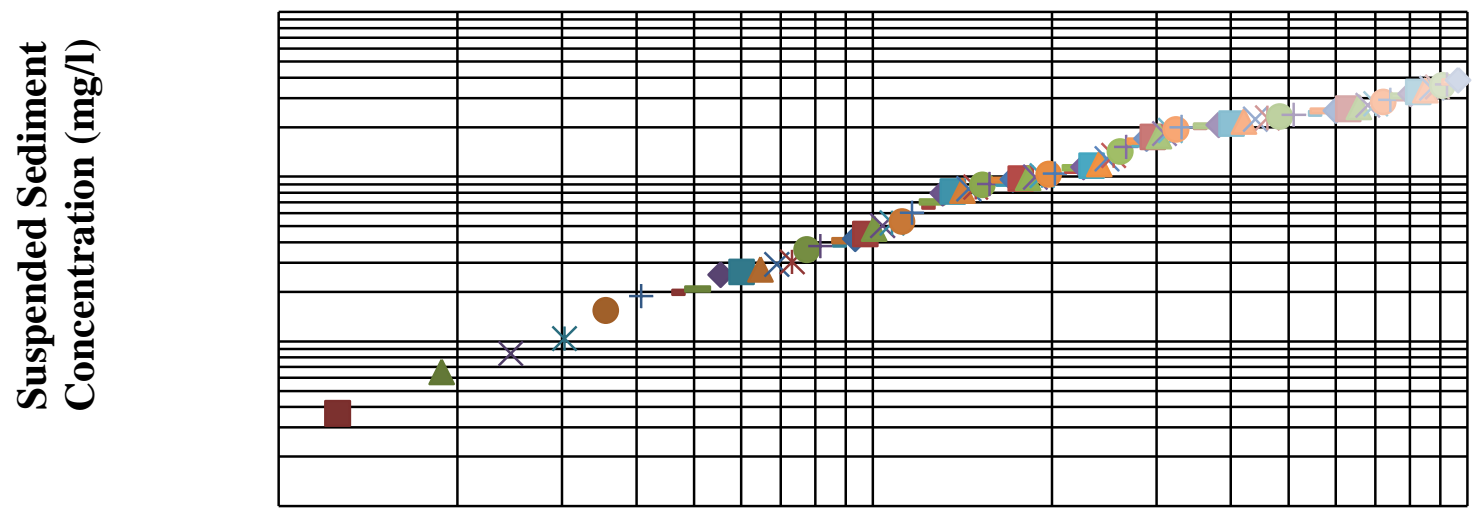

\section{Figure 4: Relationship between Suspended Sediment Concentration $\left(\mathrm{m}^{3} / \mathrm{s}\right)$ Discharge of the Nasia River}

As compared to the turbidity - discharge relation $\left(r^{2}=0.959\right)$, suspended sediment concentration strongly relates to discharge $\left(r^{2}=0.975\right)$. According to Gregory and Walling (1973) water discharge and suspended sediment may not correlate well for many reasons and these reasons may include the factors which influence runoff and also the production of sediment from a catchment. An increase in the flow rate of the Nasia River (Equation 8) however leads to proportionate increase in suspended sediment discharge.

Mean turbidity values for April, May and June 2007 were 141.74, 423.91 and 652.33 NTU respectively. Turbidity values can be seen to however increase as the rains increase or intensify. This is evident from the average turbidity values recorded for the various months. A general relationship between laboratory turbidity and discharge for the period studied is presented in Figure 5. 


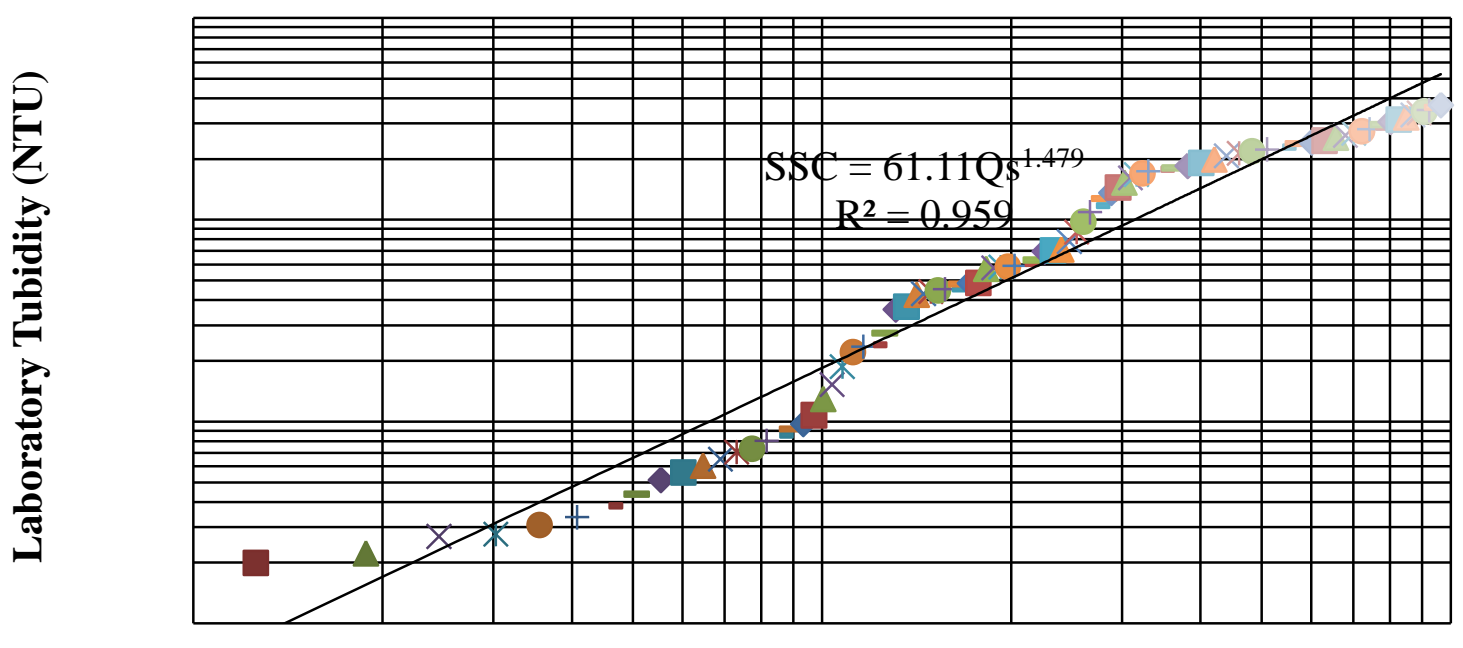

\section{Discharge $\left(\mathrm{m}^{3} / \mathbf{s}\right)$ \\ Figure 5: Relationship between Laboratory Turbidity and Discharge of the Nasia River}

From the log-log plots of Figure 5 the turbidity - discharge relation established is;

$$
\log N T U=1.479 \log Q_{s}+1.786
$$

A good fit with a coefficient of determination $\left(r^{2}\right)$ being 0.959 was observed for the basin. This relationship correlates directly with overland flow and its characteristic soil particle detachment and transport.

\section{CONCLUSIONS AND IMPLICATIONS FOR DEVELOPMENT}

Area can be said not to have a great influence on the amount of sediment produced and this is evident in the mean sediment results of the five classified drainage areas. Though catchment area has an influence on the amount of suspended sediment produced, the average slope of an area has a greater influence.

The relationship between the predicted suspended sediment and the river discharge also shows that an increase in suspended sediment produced was an indication of an increase in sediment discharge rate. An increase in the flow rate of the Nasia River therefore resulted in proportionate increase in suspended sediment discharge. This indicates that more sediment is delivered into the White Volta River as runoff from the Nasia River increases. This means also that a high level of sediment will be produced and deposited in the river bed thus reducing the carrying capacity of these systems. Flooding may also occur thus resulting in the destruction of farmlands, crops, animals, property and even human lives.

Rainfall variation has been realised to have a great influence on the difference in suspended sediment concentration and turbidity values. High turbidity values resulted in high levels of suspended sediment concentration in the river channel. High turbidity levels pointed to the fact that very fine and fine soil particles which hold soil nutrients together are being washed down to the river thus resulting in larger soil particle size on farmlands with less nutrients. 
High turbidity levels also have a great effect on the life and growth of aquatic organisms that live in the river channel. Some fishes and other organisms which will keep the eco-system in a stable state will also be affected especially their productivity.

The establishment of buffer zones and sediment reduction structures should be undertaken by farmers to help reduce the amount of suspended sediment produced from the catchment as well as trapping of sediment.

Education on the effects of land degradation on river flow should be carried-out in the study area to help reduce the amount of sediment discharged into the river channel.

\section{REFERENCES}

Adu, S. V. (1995). Soils of the Nasia River Basin, Northern Region, Ghana. Soil Research Institute (Council for Scientific and Industrial Research). Academy Post Office, Kwadaso-Kumasi, Ghana. Memoir No. 11.

Akrasi, S. A. (2005). The Assessment of Suspended Sediment Inputs to Volta Lake, Lakes and Reservoirs: Research and Management 2005 10:179-186.

Asiamah, R. D. and Antwi, B. O. (1988). 'Soil and Water Conservation in Ghana: Past, present and future activities', in FAO (ed.). Rapport sur les ressources en sols du monde, 63, Rome: FAO, 126-38.

Bandaragoda, D. J. (2001). A Framework for International Analysis for Water Resources Management in a River Basin Context. In: Bryan Bruns, D. J. and Bandaragoda, M. S. (eds). Proceedings of the Regional Workshop, 15-19 January 2001. Malanga, Indonesia.

Environmental Protection Agency (EPA). (2000). Ghana's Initial National Communication under the United Nations Framework Convention on Climate Change. Republic of Ghana, Ministry of Environment, Science and Technology. Acts Commercials Ltd, Accra, Ghana. Available at: http://www.epa.gov.gh (Cited: $24^{\text {th }}$ March 2007).

Environmental Protection Agency (EPA). (2002). National Action Programme to Combat Drought and Desertification. Accra-Ghana.

Ferguson, R. I. (1986). River Loads Underestimated By Rating Curves. Water Resources Research, Vol. 22, NO. 1, (74-76). In: Bača, P. (2002).Temporal variability of suspended sediment availability during rainfallrunoff events in a small agricultural basin. Available at: http://1:47.213.145.2/svh/ERBabstracts/Baca upraveny.pdf (Cited: $6{ }^{\text {th }}$ July 2007).

Food Agricultural Organisation (FAO). (1997). Irrigation Potential in Africa, A Basin Approach. FAO land and water bulletin 4. Food and Agriculture Organisation of the United Nations, Rome.

Food Agricultural Organisation (FAO). (2005). Aquastat Land And Water Agriculture 21. FAO information systems on water and agriculture. Food and Agriculture Organisation of the United Nations, Rome. Available at: http://www.fao.org/ag/agl/ag/w/aquastat/countries/ghana/index.stm (Cited: $10^{\text {th }}$ September 2006). 
Fournier, F. (1960). Climat et érosion: la relation entre l' erosion du sol par l'eau les precipitations atmospheriques, Paris. (210). In: Gregory K. J. and Walling, D. E. (1973). Drainage Basin Form and Process; A geomorphological approach. Edward Arnold (Publishers) Ltd, Bedford Square, London.

George, K. (2005). Strain, social and environmental consequences, and water management in the most stressed water system in Africa. International Development Center, Canada. Available at: http://reseau.crdi.ca/es/ev-1-2001-DO-TOPIC.html (Cited: $20^{\text {th }}$ October 2005).

Gippel, C. J. (1995). Potential of Turbidity Monitoring for Measuring the Transport of Suspended Solids in Streams. Hydrological Processes 9: 83-97.

Gregory, K. J. and Walling, D. E. (1973). Drainage Basin Form and Process; A Geomorphological Approach. Edward Arnold (Publishers) Ltd, Bedford Square, London.

Guy, H. P. and Norman, V. W. (1970). Field methods for measurement of fluvial sediment. Techniques of Water-Resource Investigations of the United States Geological Survey. C 2(3). In:

Gregory, K. J. and Walling, D. E. (1973). Drainage Basin Form and Process; A geomorphological approach. Edward Arnold (Publishers) Ltd, Bedford Square, London.

Holeman, J. N. (1968). The Sediment Yield of Major Rivers of the World. Water Resources Res. 4, 737-47. In: Gregory, K. J. and Walling, D. E. (1973). Drainage Basin Form and Process; A geomorphological approach. Edward Arnold (Publishers) Ltd, Bedford Square, London.

Hydrological Services Department (HSD) (2007). List of Stations in the Major Basins of Ghana. (Unpublished)

Lal, R. (1990). Soil Erosion in the Tropics: Principles and Management, McGraw Hill Inc. United States of America.

Lewis, J. (1996). Turbidity Controlled Suspended Sediment Sampling For Runoff-Event Load Estimation. Water Resources Research, 32 (7), 2299-2310.

Millar, J. (1994). Handbook for Agrohydrology, Natural Resources Institute (NRI).

Ministry of Works and Housing (MWH). (1998). Ghana's Water Resources: Management Challenges and Opportunities. Water Resources Management Study. Morgan, R. P. C. (1995). Soil Erosion \& Conservation, $2^{\text {nd }}$ ed, Addison Wesley Longman Ltd, England.

Nick Van, D.; Andreini, M.; van Edig, A. and Pawl, V. (2001). Competition for Water Resources of the Volta Basin. Proceedings of a symposium held during the sixth IAHS scientific assembly on regional management of water resources on July 2001. Maastricht, The Netherlands. IAHS publication No. 268, 2001.

Opoku-Ankoma, Y. (1986). Annual Stream flow Characteristics of Major Ghanaian Rivers. Water Resources Research Institute, Accra, Ghana. 


\section{Ghana Journal of Development Studies, Volume 7, Number $2 \mid 2010$}

Quansah, C. (1990). Soil Erosion and Conservation in the Northern and Upper Regions of Ghana. Topics in Applied Resource Management, vo1.2; 135-157.

Truhlar, J. F. (1978). Determining Suspended Sediment Loads From Turbidity Records. Hydrological Sciences-Bulletin-des Sciences Hydrologiques, 23:4. 